\title{
Synthesis of Benzothiazinophenothiazine Derivatives and their Antimicrobial Screening
}

\author{
EMMANUEL O. ADEKOLA ${ }^{1}$, BENJAMIN E EZEMA, ${ }^{1}$ JUDE I. AYOGU ${ }^{1 *}$, \\ DAVID I. UGWU ${ }^{1}$, CHIDIMMA G. EZEMA ${ }^{2}$, ABUEKWU P. NWASI ${ }^{1}$ and CHRISTIAN O. IKE
}

\author{
1Department of Pure and Industrial Chemistry,Faculty of Physical Sciences, University \\ of Nigeria, Nsukka, Synthetic Organic Chemistry Unit, 41002, Nigeria. \\ ${ }^{2}$ National Centre for Energy Research and Development, University of Nigeria, Nsukka. \\ *Corresponding author E-mail: jude.ayogu@unn.edu.ng \\ http://dx.doi.org/10.13005/ojc/300406
}

(Received: September 28, 2014; Accepted: November 06, 2014)

\begin{abstract}
The synthesis of benzothiazinophenothiazine derivatives from simple heterocyclic compounds was thoroughly investigated. The intermediate, 6-chloro-5H-benzo[a]phenothiazin-5one was afforded by the condensation of 2-aminothiophenol with 2,3-dichloro-1, 4-naphthoquinone in an alkaline medium. Further condensation of the intermediate with 2,4-diamino-6hydroxypyrimidine-5-thiol obtained by alkaline hydrolysis of 2,4-diamino-6-hydroxy-5thiacyanatopyrimidine gave 7-amino-9-hydroxy-6-8, diazabenzo[a][1,4]benzothiazino[3,2c]phenothiazine. However, facile acid-catalyzed synthesis of four other benzothiazinophenothiazine ring systems was accomplished with improved yield and lesser reaction time. The Structural confirmation was done using UV-Visible spectroscopy, FT-IR, ${ }^{1} \mathrm{H}$ and ${ }^{13} \mathrm{C}-\mathrm{NMR}$ and elemental analysis. The synthesized compounds were screened against some micro-organisms and the results showed that the complex derivatives were significantly active against the microorganisms.
\end{abstract}

Key words: Benzothiazinophenothiazine derivatives, antimicrobial screening, Sensitivity test, minimium inhibition concentration and inhibition zone diameter.

\section{INTRODUCTION}

Phenothiazines are amongst the most frequently encountered bioactive heterocycles in compound of biological interest. ${ }^{1}$ Phenothiazine derivatives have been shown to possess a broad spectrum of pharmacological activity depending on their particular structure like antiparkinsonian ${ }^{2-3}$, tranquilizer ${ }^{4}$, anti-inflamatory ${ }^{5-7}$, antimalarial ${ }^{8-9}$, antipsychotic, ${ }^{10-12}$, antimicrobial ${ }^{13-15}$, anti-tubercular 16-18, antitumor ${ }^{19-20}$, antihistaminic ${ }^{21-22}$, analgesic ${ }^{23}$, prion disease drug ${ }^{24}$. In textile, paint and plastic industries, they are used as dyes and pigments ${ }^{25-26}$ and in agricultural industries as insecticides. ${ }^{27}$ In petroleum industries, they are found useful as antioxidants in lubricants and fuels. ${ }^{28}$ it has been 
observed that some phenothiazines inhibit intracellular replication of viruses including human Immunodeficiency viruses (HIV) ${ }^{29}$. On the other hand, some have been reported to exhibit significant anticancer activity ${ }^{30-31}$. Owing to the wide range of applications of phenothiazine, intensive research has been in progress for more derivatives with highly improved pharmacological and biological activities. Hence, several papers describing the successful synthesis of these derivatives had been reported especially on the angular derivatives including the non-aza and the congeneric azaanalogues, but there are still limited literatures on the complex derivatives of this phenothiazine ring system. The past work done was based on their dye and pigment properties, not much is known of their antimicrobial properties. Therefore, the authors describe the synthesis of complex aza derivatives of benzothiazinophenothiazine and their antimicrobial screening.

\section{EXPERIMENTAL}

All chemicals used were of laboratory grade (Sigma Aldrich). The melting points were determined with a Fischer John's apparatus and were uncorrected. UV/Visible spectra were recorded on UV-25500PC series spectrophotometer using matched $1 \mathrm{~cm}$ quartz cells. The IR spectra were recorded on $8400 \mathrm{~S}$ FT-IR spectrometer using $\mathrm{KBr}$ discs (at NARICT, ZARIA). The ${ }^{1} \mathrm{H}-\mathrm{NMR}$ and ${ }^{13} \mathrm{C}$ NMR were scanned at university of stratchclyde, Scotland on a Jeol FX 90Q spectrometer using TMS as internal standard (chemical shift in $\delta$ ).. Elemental analysis was carried on $\mathrm{CHN}$ rapid analyzer and the antimicrobial screening was done at the Faculty of Pharmaceutical Sciences, University of Nigeria, Nsukka.

\section{Synthesis of 6-chloro-5H-benzo[a]phenothiazin- 5-one (1)}

To a mixture of 2-aminothiophenol (4.0 g, $32 \mathrm{mmol}$ ) and anhydrous sodium trioxocarbonate (IV) $(3.3 \mathrm{~g}, 31 \mathrm{mmol})$ in a $250 \mathrm{~mL}$ two-necked flask equipped with magnetic stirrer, thermometer and reflux condenser, was added a solution of benzene $(100 \mathrm{~mL})$ and DMF $(10 \mathrm{~mL})$. The mixture was boiled for $1 \mathrm{~h}$ and thereafter, 2,3-dichloro-1,4naphthoquinone $(7.26 \mathrm{~g}, 32 \mathrm{mmol}$ ) was added and the entire solution refluxed with continuous stirring for more $7 \mathrm{~h}$ at $78-80{ }^{\circ} \mathrm{C}$. Then, the solvent was distilled off and the slurry poured into water and stirred for $20 \mathrm{~min}$ to dissolve the inorganic materials. It was left overnight, filtered and recrystallized from methanol-acetone mixture to obtain a purple microcrystalline powder of $\mathbf{1}(8.5 \mathrm{~g}, 85 \%$ yield). m.p $234{ }^{\circ} \mathrm{C} ; \mathrm{Uv}-\mathrm{V}(\mathrm{MeOH}) \lambda_{\max }(\mathrm{nm}) \log (\varepsilon): 210$ (1.978), 221 (1.4779), 228 (1.2517), 234 (1.3543), 247 (0.2255), 255 (0.5149), 261 (1.4326), 266 (1.2138), 289 (2.3308), 314 (2.3640), 379 (2.3041), 491 (2.2271); FT-IR (KBr): $v_{\max } 3063 \mathrm{~cm}^{-1}$ (aromatic C-H str.), $1631 \mathrm{~cm}^{-1}(\mathrm{C}=\mathrm{O}), 1502$ (aromatic $\mathrm{C}=\mathrm{N}$ ), 1467 (aromatic C=C) $780(\mathrm{C}-\mathrm{Cl}), 1292,1228,1155,1082$, 1039, 902, 680, 567 and $462 \mathrm{~cm}^{-1}$.

Synthesis of 7-amino-9-hydroxy-6, 8diazabenzo[a] $[1,4]$ benzothiazino $[3,2$ c]phenothizine (2)

The same procedure as in compound 1 above was employed using 2,4-diamino-6hydroxypyrimidine-5-thiol $(1.0 \mathrm{~g}, 6 \mathrm{mmol})$ and anhydrous sodium trioxocarbonate (IV) (1.5 g, $14 \mathrm{mmol}$ ) but 6-chloro-5H-benzo[a] phenothiazin5 -one $(1.8 \mathrm{~g}, 6 \mathrm{mmol})$ in the second stage instead of 2,3-dichloro-1,4-naphthoquinone to give 2 (2.46 g $84 \%$ yield) as purple-red crystals; m.p. > $300^{\circ} \mathrm{C}$; Uv-V (MeOH) (nm) log): 780 (1.7000), 745 (1.7204), 688 (1.7704), 486 (2.5758), 380 (2.6022), 319 (2.6437), 265 (2.8636), 254 (2.7968), 247 (2.7875); IR (KBr): $v_{\max } 3761(\mathrm{OH}), 3400,3331$ ( > N-H str) 3063, (aromatic C-H str.), 1608 (arom. C=N) 1494, 1452 (arom. C=C), 1300, 1242, 1151, 1087, 1024, $877,850,758,673,642,538$ and $455 \mathrm{~cm}^{-1} ;{ }^{1} \mathrm{H}-\mathrm{NMR}$ (DMSO: $d_{6}$ ) $\delta: 8.87\left(2 \mathrm{H}, \mathrm{dd}, \mathrm{J}_{1}=7.87, \mathrm{~J}_{2}=1.36 \mathrm{H}_{\mathrm{z}}\right.$ ), $8.24\left(2 \mathrm{H}, \mathrm{dd}, \mathrm{J}_{1}=7.55, \mathrm{~J}_{2}=1.61 \mathrm{~Hz}\right) .8 .08(4 \mathrm{H}, \mathrm{m}, \mathrm{Ar}-$ H), 7.92-7.67 (4H, m, 1-H, 2-H, 3-H), $5.46(1 \mathrm{H}, \mathrm{s}, 9-$ $\mathrm{OH}) ;{ }^{13} \mathrm{C}-\mathrm{NMR}$ (DMSO) $\delta$ : Few peaks, due to the insolubility of the compound. Absence of chemical shift at $150 \mathrm{ppm}$ and above indicates the absence of $\mathrm{C}=\mathrm{O}$. Analysis calculated for $\mathrm{C}_{20} \mathrm{H}_{11} \mathrm{~N}_{5} \mathrm{OS}_{2}$ : $\mathrm{C}$, 59.84, H, 2.76, N, 17.44 and S, 15.97. Found: C, $59.88, \mathrm{H}, 2.81, \mathrm{~N}, 17.45$ and $\mathrm{S}, 15.99$.

Synthesis of 7,14-diethylthio-9,12-dihydroxy$6,8,13,15$-tetraazabenzo[a] $[1,4]$ benzothiazino [3,2-c]phenothiazine. (3)

To 4-amino-2-ethylthio-6-hydroxypyri midine-5-thiol (2 g; $10 \mathrm{mmol}$ ) in $250 \mathrm{~mL}$ two-necked flask equipped with magnetic stirrer, thermometer and a reflux condenser, was added absolute 
ethanol $(100 \mathrm{~mL})$ and $15 \% \mathrm{HCl}(10 \mathrm{~mL})$. The mixture was warmed to dissolve the solid, 2,3dichloro-1,4-naphthoquionone (1.1 g; $5 \mathrm{mmol}$ ) was added and the mixture refluxed on a water bath for $6 \mathrm{~h}$ at $78^{\circ} \mathrm{C}$. On refluxing, an immediate appearance of orange brown ppt was observed which turned blue and persisted. Thereafter, the mixture was poured in cold water, stirred, filtered and the residue crystallized from acetonemethanol mixture to obtain 3 (3.2 g; $91 \%$ yield) as blue powder. m.p > $310^{\circ} \mathrm{C}$; Uv-V $(\mathrm{MeOH}) \quad(\mathrm{nm})$ $\log (): 748$ (1.2533), 539 (2.4100), 328 (3.2316), 322 (3.2249), 305 (3.2634), 276 (1.5901), 266 (1.7812), 257 (1.0315), 239 (1.0895), 233 (0.9881), 288 (0.8554), 222 (1.3721); IR (KBr) $v_{\max } 3755,3400$ $(\mathrm{OH}), 3184$ (aromatic C-H str.), 2937 (C-H str of $\mathrm{CH}_{3}$ or $\mathrm{CH}_{2}$ ), 1626, 1556, (aromatic $\mathrm{C}=\mathrm{N}$ ), 1518, 1446 (aromatic $\mathrm{C}=\mathrm{C}$ ), 1325, 1276, 1224, 1130, 1095, 964, 885, 823, 779, 700, 648, 561, $447 \mathrm{~cm}^{-1}$; ${ }^{1} \mathrm{H}-N M R\left(D M S O: d_{6}\right) \delta: 8.08(4 \mathrm{H}, \mathrm{m}, \mathrm{Ar}-\mathrm{H}), 7.91(4 \mathrm{H}$, $\left.\mathrm{td}, \mathrm{J}_{1}=6.72, \mathrm{~J}_{2}=5.89, \mathrm{~J}_{3}=3.44 \mathrm{H}_{\mathrm{z}}, \operatorname{Ar}-\mathrm{H}\right), 3.3(2 \mathrm{H}, \mathrm{q}$, $\left.\mathrm{J}_{1}=8.16, \mathrm{~J}_{2}=7.3 \mathrm{~Hz},-\mathrm{SCH}_{2} \mathrm{CH}_{3}\right) 3.06(3 \mathrm{H}, \mathrm{t}$, $\left.\mathrm{SCH}_{2} \mathrm{CH}_{3}\right), 1.33\left(3 \mathrm{H}, \mathrm{dt}, \mathrm{J}_{2}=54.74, \mathrm{~J}_{2}=7.41 \mathrm{H}_{\mathrm{z}}\right)$; ${ }^{13} \mathrm{C}-\mathrm{NMR}$ (DMSO) $\delta:$ 142.98-127.63 ( $\left.\mathrm{C}_{1}-\mathrm{C}_{9}, \mathrm{Ar}-\mathrm{C}\right)$, 15.19 (aliphatic carbon). Analysis: Calculated for $\mathrm{C}_{19} \mathrm{H}_{11} \mathrm{~N}_{7} \mathrm{O}_{2} \mathrm{~S}_{2}: \mathrm{C}, 52.65, \mathrm{H}, 2.56, \mathrm{~N}, 22.62, \mathrm{~S}, 14.79$. Found: C, 52.72, H, 2.59, N, 22.60, S, 14.90 .

\section{Synthesis of 8,3-dimethoxy-9,12-diazabenzo[a] $[1,4]$ benzothiazino[3,2-c]phenothiazine (4)}

3-Amino-6-methoxypyridin-2-thiol (2 g; 13 $\mathrm{mmol})$ in absolute ethanol $(100 \mathrm{~mL})$ was placed in 2-necked reaction flask containing $10 \mathrm{~mL}$ of $15 \%$ $\mathrm{HCl}$ and warmed. 2,3-dichloro-1,4-naphthoquinone $(1.45 \mathrm{~g}, 6 \mathrm{mmol})$ was then added and the mixture refluxed on a water bath for $6.5 \mathrm{~h}$ at $78{ }^{\circ} \mathrm{C}$. The initially formed yellow precipitate turned darkbrown which persisted throughout the reflux period. The mixture was then poured into a beaker and heated for $15 \mathrm{~min}$ to evaporate the remaining solvent. It was diluted twice with water and cooled. The darkbrown residue was collected after filtration, and crystallization from acetone-methanol mixture gave a brown microcrystalline powder of 4 (3.40 g; $94 \%$ yield). m.p > $310^{\circ} \mathrm{C}$; Uv-V (MeOH) (nm) log(: 749 (1.6377), 478 (2.5529), 334 (3.0278), 296 (2.8135), 275 (1.2669), 269 (1.5525), 257 (1.0313), 246 (1.1897), 239 (1.4659), 228 (1.3409), 222 (1.5827), 212 (1.2566), 203 (1.6419); IR (KBr) 3088 (aromatic C-H str.), 1587 ( $\mathrm{C}=\mathrm{N}$ aromatic), 1504 (aromatic
$\mathrm{C}=\mathrm{C}), 1346,1278,1147,1087,1022,889,831$, 781, 692, 648, 555 and $462 \mathrm{~cm}^{-1} ;{ }^{1} \mathrm{H}-\mathrm{NMR}$ (DMSO: $\left.\mathrm{d}_{6}\right) \delta: 10.57(2 \mathrm{H}, \mathrm{d}), 10.31(2 \mathrm{H}, \mathrm{d}, \mathrm{J}=7.51 \mathrm{~Hz}), 7.66$ (4H, s, Het. Ar-H), $7.31(4 \mathrm{H}, \mathrm{s}, \mathrm{Ar}-\mathrm{H}), 4.28(3 \mathrm{H}, \mathrm{d},-$ $\left.\mathrm{OCH}_{3}\right) \cdot{ }^{13} \mathrm{C}-\mathrm{NMR}$ (DMSO) $\delta$ : There were few peaks due to difficulty in the solubility of the compound; 24.63-15.05 ppm (aliphatic carbon). Analysis: Calculated for $\mathrm{C}_{22} \mathrm{H}_{14} \mathrm{~N}_{4} \mathrm{O}_{2} \mathrm{~S}_{2}$ : C, 61.38, $\mathrm{H}, 3.28, \mathrm{~N}$, 13.01, S, 14.90. Found: C, 61.45, H, 3.33, N, 13.21, S, 15.10 .

Synthesis of 6,13-dichloro-3, 10-diethylthio-1,8dihydroxy-2,4,9,11-tetrazatriphenodithiazine (5)

A mixture of 4-amino-2-ethylthio-6hydroxypyrimidine-5-thiol (4 g; $19 \mathrm{mmol})$, absolute ethanol $(150 \mathrm{~mL})$ and $10 \mathrm{~mL}$ of $15 \% \mathrm{HCl}$ was warmed and tetrachloro-1,4-benzoquinone (2 g; 8 $\mathrm{mmol})$ was then added. The mixture was refluxed on a water bath with continuous stirring for $6 \mathrm{~h}$. An immediate formation of a yellow clear solution and then observation of yellowish-red precipitate occurs. At the end of the reflux period, the mixture was poured into a beaker, filtered and recrystallized from aqueous acetone to obtain a greenish yellow powder, 5 ((5.3,73 \% yield g). m.p > $310^{\circ} \mathrm{C}$; Uv-V $(\mathrm{MeOH}) \quad(\mathrm{nm}) \log (: 753$ (1.1864), 671 (1.2357), 612 (1.5859), 531 (1.5920), 491 (1.6538), 322 (3.2634), 305 (3.2993), 274 (1.1819), 257 (1.4759), 251 (1.7954), 246 (1.2910); IR (KBr): 3751,3375 $(\mathrm{OH}), 3196,(\mathrm{C}-\mathrm{H}$ str.), 1626 (aromatic $\mathrm{C}=\mathrm{N}), 1548$, 1437 (aromatic $\mathrm{C}=\mathrm{C}$ ), 1319, 1282, 1215, 1089, 962, 881, 773, 698, 545 and $451 \mathrm{~cm}^{-1}$ Analysis: Calculated for $\mathrm{C}_{16} \mathrm{H}_{8} \mathrm{Cl}_{2} \mathrm{~N}_{6} \mathrm{O}_{2} \mathrm{~S}_{2}: \mathrm{C}, 42.58, \mathrm{H}, 1.79$, Cl, 15.70, N, 18.62, S, 14.21. Found: C, 42.67, H, 1.92, Cl, 15.73, N, 18.60, S, 14.26.

\section{Synthesis of 6,13-dichloro-3-methyl-9-methoxy- 1-hydroxy-2,4,8-triazatriphenodithiazine (6)}

Mixture of 3-amino-6-methoxypyridine-2-

thiol (2 g, $12 \mathrm{mmol}), 4$-amino-2-methyl-6hydroxypyrimidine-5-thiol ( $2 \mathrm{~g}$; $10 \mathrm{mmol}$ ) was placed in a reaction flask equipped with magnetic stirrer, thermometer and reflux condenser. Absolute ethanol $(120 \mathrm{~mL})$ and $10 \mathrm{~mL}$ of $15 \% \mathrm{HCl}$ were then added and solution was warmed to dissolve. Tetrachloro-1,4-benzoquinone ( $3 \mathrm{~g}, 12 \mathrm{mmol}$ ) was later added and the mixture refluxed with continuous stirring for $7 \mathrm{~h}$ at $78^{\circ} \mathrm{C}$. At the end of the reflux period, the mixture was poured into a clean beaker and $100 \mathrm{~mL}$ of water was added, it was 
heated for $15 \mathrm{~min}$ and cooled. The crude product was collected by filtration, dried in an oven and crystallized from acetone-methanol mixture to give 6 as purple powder $(4.79 \mathrm{~g}, 86 \%$ yield). m.p $>300$ ${ }^{\circ} \mathrm{C}$; Uv-V (MeOH) (nm) log(: 750 (1.5670), 583 (2.1691), 343 (2.6682), 257 (3.0207), 228 (2.3856), 223 (1.2553); IR (KBr) : 3751, $3346(\mathrm{OH}), 3119$ (aromatic C-H-stretch), 2918, 2852 (C-H stretch of $\mathrm{CH}_{3}, \mathrm{CH}_{2}$ ) 1641, 1595 (aromatic $\mathrm{C}=\mathrm{N}$ ), 1546, 1444 (aromatic C=C) 1354, 1273, 1155, 1085, 1012, 912 , $833,777,723,677,608,553$, and $509 \mathrm{~cm}^{-1}$; ${ }^{1} \mathrm{H}-\mathrm{NMR}$ $\left(\right.$ DMSO-d $\left._{6}\right)$ ) $11.64(1 \mathrm{H}, \mathrm{s}), 7.01(2 \mathrm{H}, \mathrm{d}, \mathrm{J}=144.25$ Hz Het. Ar-H), $2.4\left(3 \mathrm{H}, \mathrm{s},-\mathrm{OCH}_{3}\right), 1.45\left(3 \mathrm{H}, \mathrm{s},-\mathrm{CH}_{3}\right)$; ${ }^{13} \mathrm{C}$-NMR (DMSO) $\delta: 165.96,162.37,159.79$ (Ar-C), $88.53(\mathrm{C}=\mathrm{C}), 21.43\left(-\mathrm{CH}_{3}\right.$, aliphatic carbon); Analysis: Calculated for $\mathrm{C}_{17} \mathrm{H}_{9} \mathrm{Cl}_{2} \mathrm{~N}_{5} \mathrm{O}_{2} \mathrm{~S}_{2}: \mathrm{C}, 45.34$, $\mathrm{H}, 2.01, \mathrm{Cl}, 15.75, \mathrm{~N}, 15.55, \mathrm{~S}, 14.24$.Found: C, 45.42, H, 2.30, Cl, 15.86, N, 15.53, S, 14.33.

\section{RESULTS AND DISCUSSION}

2,3-Dichloro-1,4-naphthoquinone was refluxed with 2-aminothiophenol to yield 6-chloro$5 \mathrm{H}$ - benzo[a]phenothiazin-5-one 1 . Compound 1 on treatment with 2,4-diamino-6-hydroxypyrimidine-5thiol , obtained from alkaline hydrolysis of 2,4diamino-6-hydroxy-5-thiacyanatopyrimidine, in the presence of anhydrous $\mathrm{Na}_{2} \mathrm{CO}_{3}$ under reflux yielded 7 - a m ino- 9 - hy droxy- 6,8 - diazabenzo [a][1,4]benzothiazino[3,2-c]phenothiazine 2 . The second derivative 7,14-diethylthio-9,12-dihydroxy6,8,13,15-tetrazabenzo[a][1,4]benzothiazino[3,2c]phenothiazine 3 was synthesized as a blue powder by condensation of 2 moles of 4-amino-2ethylthio-6-hydroxypyrimidine-5-thiol with a mole of 2,3-dichloro-1,4-naphthoquinone in an acid medium. 3-Amino-6-methoxypyridine-2-thiol also

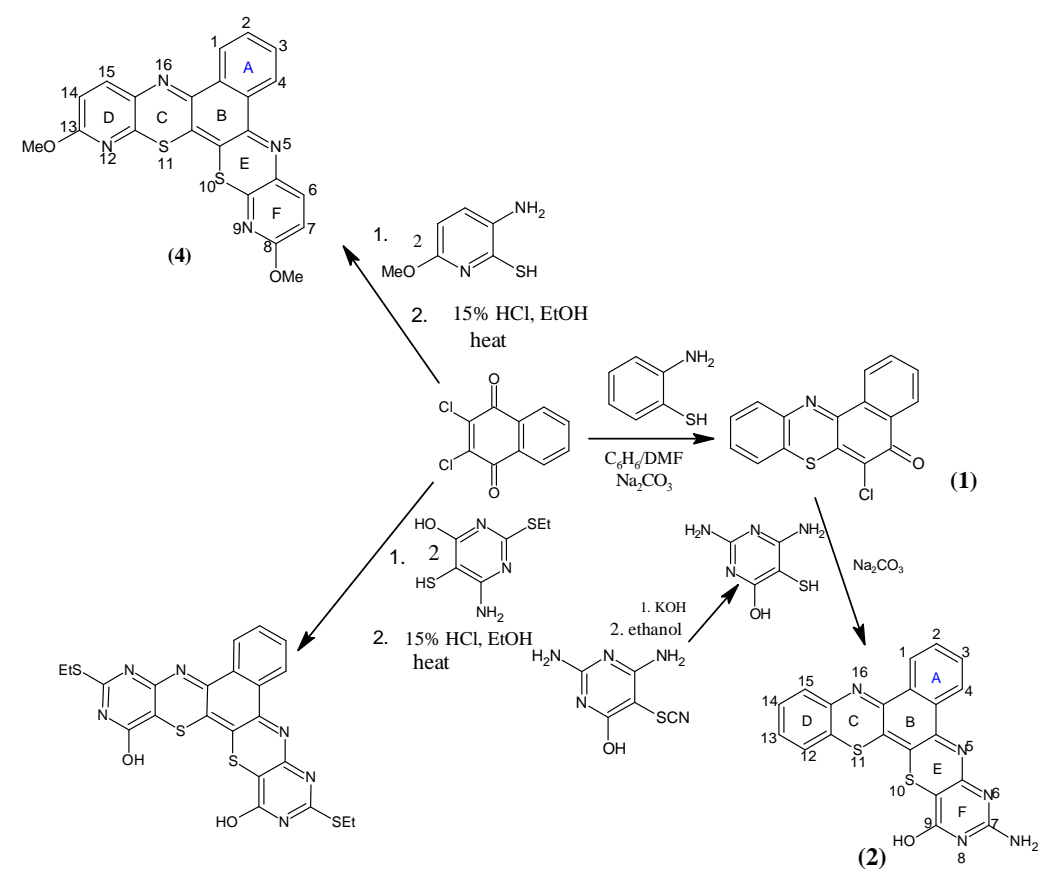

(3)

Scheme 1:

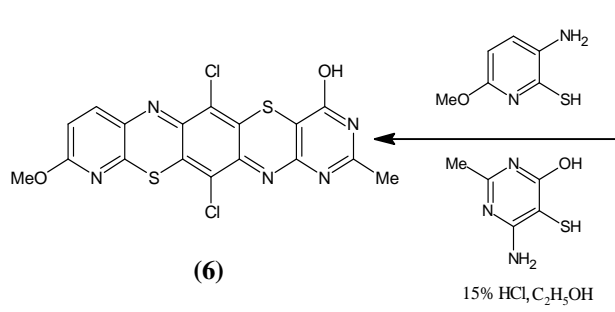

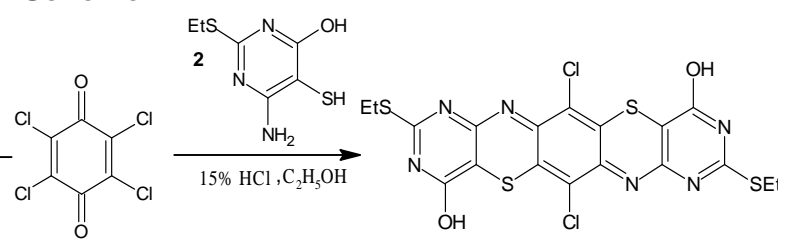

(5)

Scheme 2: 
condensed with the 2,3-dichloro-1,4naphthoquinone in the presence of $15 \% \mathrm{HCl}$ and Ethanol to furnished a good yield of 8,13-dimethoxy9,12-diazabenzo[a][1,4]benzothiazino[3,2c]phenothiazine 4 as a brown crystalline powder Scheme 1.

However, condensation of 2 moles of the 4-amino-2-ethylthio-6-hydroxypyrimidine-5-thiol with 1 mole of tetrachloro-1,4-benzoquinone in an acid medium gave 6,13-dichloro-3,10-diethylthio1,8-dihydroxy-2,4,9,11-tetraazatriphenodithiazine $\mathbf{5}$ as greenish yellow powder. Another complex azatriphenodithiazine ring system (6,13-dichloro3-methyl-9-methoxy-1-hydroxy-2, 4, 8triazatriphenodithiazine) 6 was synthesized as purple crystalline powder by condensing 3-amino6-methoxypyridine-2-thiol, tetrachloro-1,4benzoquinone and 4-amino-2-methyl-6-hydroxy-5thiopyrimidine Scheme 2.

The IR spectra of compound 1 showed $>\mathrm{NH}$ stretching vibration as weak band in the region $3125-3063 \mathrm{~cm}^{-1}$ and the $>\mathrm{C}=\mathrm{O}$ as strong band at $1631 \mathrm{~cm}^{-1}$. Bands at $1502 \mathrm{~cm}^{-1}$ and $1608 \mathrm{~cm}^{-1}$ were assigned to $\mathrm{C}=\mathrm{C}$ and $\mathrm{C}=\mathrm{N}$ stretching vibrations in

Table 1: Results of Antimicrobial Sensitivity Test of the Synthesized Compounds

\begin{tabular}{|c|c|c|c|c|c|c|c|c|}
\hline \multirow[t]{2}{*}{ Compound } & \multicolumn{3}{|c|}{ Gram-positive bacteria } & \multicolumn{3}{|c|}{ Gram-negative bacteria } & \multicolumn{2}{|c|}{ Fungi Organisms } \\
\hline & $\begin{array}{c}\text { B. } \\
\text { subtilis }\end{array}$ & $\begin{array}{c}\text { B. } \\
\text { cereus }\end{array}$ & $\begin{array}{c}\text { S. } \\
\text { aureus }\end{array}$ & $\begin{array}{c}P \\
\text { aeruginosa }\end{array}$ & $\begin{array}{c}E . \\
\text { coli }\end{array}$ & $\begin{array}{c}\text { K. } \\
\text { pneumoniae }\end{array}$ & $\begin{array}{c}\text { C. } \\
\text { albican }\end{array}$ & $\begin{array}{c}\text { A. } \\
\text { niger }\end{array}$ \\
\hline 1 & + & + & + & + & - & + & - & + \\
\hline 2 & + & ++ & + & + & - & - & + & + \\
\hline 3 & +++ & +++ & +++ & + & - & + & +++ & +++ \\
\hline 4 & + & + & - & - & + & - & ++ & + \\
\hline 5 & + & ++ & - & - & + & - & - & ++ \\
\hline 6 & - & + & - & + & - & + & + & - \\
\hline Rf 1 & ++ & ++ & +++ & ++ & + & ++ & - & - \\
\hline $\mathrm{Rf} 2$ & - & - & - & - & - & - & ++ & +++ \\
\hline
\end{tabular}

$\begin{array}{ll}+=\text { sensitive } & \text { Rf } 1, \text { Rf } 2 \text { (reference drugs). } \\ ++=\text { moderately sensitive } & \text { Rf } 1 \text { (Ciprofloxacin, antibacteria) } \\ -=\text { resistance } & \text { Rf } 2 \text { (Ketoconazole, antifungi) }\end{array}$

Table 2: Results of the Inhibition Zones Diameter $(\mathrm{mm})$

\begin{tabular}{|c|c|c|c|c|c|c|c|c|}
\hline \multirow[t]{2}{*}{ Compound } & \multicolumn{3}{|c|}{ Gram-positive bacteria } & \multicolumn{3}{|c|}{ Gram-negative bacteria } & \multicolumn{2}{|c|}{ Fungi Organisms } \\
\hline & $\begin{array}{c}\text { B. } \\
\text { subtilis }\end{array}$ & $\begin{array}{c}\text { B. } \\
\text { cereus }\end{array}$ & $\begin{array}{c}\text { S. } \\
\text { aureus }\end{array}$ & $\begin{array}{c}P . \\
\text { aeruginosa }\end{array}$ & $\begin{array}{c}E . \\
\text { coli }\end{array}$ & $\begin{array}{c}\text { K. } \\
\text { pneumoniae }\end{array}$ & $\begin{array}{c}\text { C. } \\
\text { albican }\end{array}$ & $\begin{array}{c}\text { A. } \\
\text { niger }\end{array}$ \\
\hline 1 & 10 & 9 & 9 & 11 & 4 & 10 & 7 & 10 \\
\hline 2 & 12 & 15 & 11 & 9 & 5 & - & 10 & 9 \\
\hline 3 & 22 & 21 & 18 & 8 & - & 12 & 22 & 21 \\
\hline 4 & 8 & 12 & - & - & 9 & 6 & 16 & 12 \\
\hline 5 & 11 & 17 & - & - & 8 & - & 5 & 18 \\
\hline 6 & 5 & 10 & - & 10 & - & 8 & 11 & - \\
\hline $\mathrm{Rf} 1$ & 17 & 17 & 20 & 13 & 8 & 15 & - & - \\
\hline $\mathrm{Rf} 2$ & - & - & - & - & - & - & 16 & 21 \\
\hline
\end{tabular}

The compounds with the IZD > 8 were considered to be sensitive \& active against the microorganisms, and upon serial dilution, gave the MIC. The higher the IZD values, the higher the activity. 
both compound 1 and 2 respectively. The disappearance of a band due to $\mathrm{C}=\mathrm{O}$ and the appearance of new band due to $\mathrm{C}=\mathrm{N}$ at $1608 \mathrm{~cm}^{-1}$ coupled with a shift in the absorption maxima from $491 \mathrm{~nm}$ in compound 1 to $780 \mathrm{~nm}$ in compound $\mathbf{2}$, because of double bond extension, indicated the formation of 2 from $\mathbf{1}$. The formations of 3 and 4 were also implicated by the appearance of bands $1556-1626 \mathrm{~cm}^{-1}$ and $1587 \mathrm{~cm}^{-1}(\mathrm{C}=\mathrm{N}), 561-648 \mathrm{~cm}^{-}$ ${ }^{1}$ and $648-692 \mathrm{~cm}^{-1}$ (C-S-C) for compounds 3 and 4 respectively and disappearance of the band for the $-\mathrm{NH}_{2}$ group in the precursor. Furthermore, the bands at $3375 \mathrm{~cm}^{-1}(\mathrm{OH}), 3196 \mathrm{~cm}^{-1}$ (C-H str. aromatic), 1626 (aromatic $\mathrm{C}=\mathrm{N}$ ), $1548-1437 \mathrm{~cm}^{-1}$ (aromatic $\mathrm{C}=\mathrm{C}$ ) and 698,545 (C-S-C in the thiazine ring) were in agreement with the assigned structure of compound 5 likewise those at $3751-3346 \mathrm{~cm}^{-1}(\mathrm{OH})$, 3119 (aromatic C-H str), $2918-2852 \mathrm{~cm}^{-1}(\mathrm{C}-\mathrm{H}$ str of $\mathrm{CH}_{2}, \mathrm{CH}_{3}$ ), 1641- $1595 \mathrm{~cm}^{-1}$ (aromatic $\mathrm{C}=\mathrm{N}$ ), 1546$1444 \mathrm{~cm}^{-1}$ (aromatic $\left.\mathrm{C}=\mathrm{C}\right), 912-833 \mathrm{~cm}^{-1}(\mathrm{CH}-$ bend in substd benzene ring), $777 \mathrm{~cm}^{-1}(\mathrm{C}-\mathrm{Cl})$ and 677 $609 \mathrm{~cm}^{-1}$ (C-S-C in the thiazine ring) were consistent with the structure of compound 6 .

In the ${ }^{1} \mathrm{H}-\mathrm{NMR}$ spectra of compounds 2- $\mathbf{4}$, the multiplet due to aromatic protons appeared in the region $\delta$ 8.87- 7.91. The protons of the methine group and methyl group in $-\mathrm{SCH}_{2} \mathrm{CH}_{3}$ appeared at $\delta 3.30$ and 3.06 respectively in compound $\mathbf{3}$. The peaks due to the four protons in pyridine rings of compounds 4 and 6 occurred between $\delta$ 7.66-7.01. The $-\mathrm{OCH}_{3}$ protons in these two compounds showed a singlet in the region $\delta 2.40-4.28$ likewise the $-\mathrm{CH}_{3}$ protons in compound 6 at $\delta 1.45$. The structural confirmation of the synthesized compounds was achieved with elemental analysis. With the exception of compounds $\mathbf{4}$ and $\mathbf{5}$ which showed few peaks due to the insolubility, the ${ }^{13} \mathrm{C}$ NMR of others led credence to the establishment of their structures.

\section{Antimicrobial activity}

All the synthesized compounds were screened for their antimicrobial activity at concentration $20 \mathrm{mg} / \mathrm{disc}$ in agar media following the method of Bauer et al. ${ }^{32}$ Using Ciprofloxacin, an antibacterial and Ketoconazole, an antifungal activity as reference drugs, the compounds were screened against eight (8) micro-organisms, viz: Bacillus subtitis, Bacillus cereus, Staphylococcus aureus, Pseudomonas aeruginosa, Escherichia coli, Klebsiella pneumonia, Candida albican and Aspergillus niger. This was carried under sensitivity test and minimium inhibitory concentration (MIC).

\section{Sensitivity Test}

This assay was conducted by applying agar-well diffusion method ${ }^{33}$ using a concentration of $20 \mathrm{mg} / \mathrm{mL}$ of each compound. From the result (Table 1), the compounds showed significant activity against the test organisms except $E$. coli which was only sensitive to compounds 4 and $\mathbf{5}$. Bacillus cereus was sensitive to all the compounds. S.aureus, $P$. aeruginosa and $K$. pneumonia were resistant to compounds 4 and $\mathbf{5}$, but were sensitive to other compounds.

Table 3: Minimum Inhibitory Concentration of the Compounds ( $\mathrm{mg} / \mathrm{ml})$

\begin{tabular}{|c|c|c|c|c|c|c|c|c|}
\hline \multirow[t]{2}{*}{ Compound } & \multicolumn{3}{|c|}{ Gram-positive bacteria } & \multicolumn{3}{|c|}{ Gram-negative bacteria } & \multicolumn{2}{|c|}{ Fungi Organisms } \\
\hline & $\begin{array}{c}\text { B. } \\
\text { subtilis }\end{array}$ & $\begin{array}{c}\text { B. } \\
\text { cereus }\end{array}$ & $\begin{array}{c}\text { S. } \\
\text { aureus }\end{array}$ & $\begin{array}{c}P . \\
\text { aeruginosa }\end{array}$ & $\begin{array}{l}\text { E. } \\
\text { coli }\end{array}$ & $\begin{array}{c}K . \\
\text { pneumoniae }\end{array}$ & $\begin{array}{c}C . \\
\text { albican }\end{array}$ & $\begin{array}{c}\text { A. } \\
\text { niger }\end{array}$ \\
\hline 1 & 0.1738 & 0.0871 & 0.1202 & 0.1514 & - & 0.1819 & - & 0.0912 \\
\hline 2 & 0.1254 & 0.1047 & 0.0794 & 0.1202 & - & - & 0.1819 & 0.0912 \\
\hline 3 & 0.0633 & 0.0505 & 0.0398 & 0.585 & - & 0.1514 & 0.1659 & 0.0603 \\
\hline 4 & 0.1819 & 0.1738 & - & - & 0.1445 & - & 0.0724 & 0.1738 \\
\hline 5 & 0.1445 & 0.1905 & - & - & 0.1689 & - & - & 0.1380 \\
\hline 6 & - & 0.1521 & - & 0.1933 & - & 0.1831 & 0.1162 & - \\
\hline $\mathrm{Rf} 1$ & 0.0212 & 0.0315 & 0.0213 & 0.0323 & 0.1677 & 0.0567 & - & - \\
\hline Rf 2 & - & - & - & - & - & - & 0.0622 & 0.1356 \\
\hline
\end{tabular}


Minimum Inhibitory Concentration (MIC) Determination

This was carried out using agar dilution following the procedure outlined by chemical laboratory Standards Institute (CLSI) ${ }^{34}$ using the following serial dilutions $1,0.5,0.25,0.125$ and 0.0625 . Almost all the synthesized phenothiazine derivatives were active against the microorganisms even at very low concentrations following from the fact that the lower the MIC values, the higher the activity. Compound $\mathbf{3}$ has the highest MIC values against bacteria which ranged from 0.0398- 0.1585 $\mathrm{mg} / \mathrm{mL}$ (Table 3). There was no MIC for compound 4 and 5 against $S$. aureus and $P$. aeruginosa respectively likewise for compounds $\mathbf{1}, \mathbf{2}$ \& $\mathbf{3}$ against $E$. coli which indicated that the listed microorganisms were highly resistant to the respective compounds. The entire compounds were very active against B.cereus and B.substilis at lower MIC values. All the compounds were highly active against the fungi with an exception of $C$. albican which showed resistance to compounds 1 and 5 .All the compounds were very active against the fungi, $A$. niger except compound $\mathbf{6}$. The reference drugs used were all active against the microorganisms with MIC lower than the synthesized compounds except in A.niger (see table 3).

\section{REFERENCES}

1 Sharma, R.; Samadhiya, P.; Srivastava, S. D.; Srivastava, S .K.; Synthesis and biological activity of 2-oxo-azetidine derivatives of phenothiazin,. Org Commun, 2011, 4(2), 4251

Khanna, R.; Palit, G.; Srivastava, V. K.; Shanker, K.; Newer Heterocycles of Phenothiazine and their Antiparkinsonian Activity, Indian J Chem , 1990, 29B , 556560.

3 Meghasham, N.N., Mahesh, K.G; Pravin, K.G.; Microwave Mediated Synthesis Of Pharmacological Active Substituted Derivatives of 2-(4/-Phenothiazinyl Pyrazolyl) Pyrroles. World Journ of Pharm Res, 2014, 3(4), 1064-1073.

4 Ei-Said, M.K. Pharmazie, 1981, 36, 678

5 Tilak, S.R; Tyagi, R.; Goel, B.; Saxena, K.K.; Synthesis and Anti-Inflammatory Activity of Some Potential Cyclic Phenothiazines, Indian Drugs. 1998, 35: 221

Sadanandam, Y.S; Shetty, M.M; Rao, A. B.; Rambabu $\mathrm{Y}, 10 \mathrm{H}-$ Phenothiazines: A New Class of Enzyme Inhibitors for Inflammatory Diseases, Eur J Med Chem, 2009, 44, 197202

7 Rajasekaran, A.; Thampi, P. P.; Synthesis and anti-inflammatory activity of some 10[(1 - acyl-1htetrazol-5-yl)ethyl-10phenothiazine, Acta Pharm. Turcica, 2003, 45, 227-232

Dominguez, J. N.; Lopez, S.; Charris, J.;
Iarruso, L.; Lobo, G.; Semenow, A.; Olson, J. E.; Rosenthal, P.J.; Synthesis and Antimalarial Effects of Phenothaizine Inhibitors of Plasmodium Falciparium Cysteine Protease, J Med Chem, 1997, 40, 2726-2732.

9 Kalkanidis, M; Klonis, N.; Tilley, L.; Deady L.W.; Novel Phenothiazine Antimalarial: Synthesis, Antimalarial Activities and Inhibition of the Formation of Beta-haematin. Biochem Pharmacol, 2002, 63(5), 833.

10 Lin, G.; Medha, K.K; Synthesis of the Piperidinone Metabolites of Piperidine-type Phenothiazine Antipsychotic Drugs via Ruthenium Tetraoxide Oxidation, J Heterocycl Chem, 1991, 28, 215

11 Mohamed, F. A.; Mohamed, H. A.; Hussein, S. A.; Ahmed, S.A.; A Validated Spectrofluorimetric Method for Determination of some Psychoactive Drugs, J Pharm Biomed Analysis, 2005, 39, 139-146.

Wen, B.; Zhou, M.; Metabolic activation of the phenothiazine antipsychotics chlorpromazine and thioridazine to electrophilic iminoquinone species in human liver microsomes and recombinant $\mathrm{P} 450 \mathrm{~s}$, Chemico-Biol Interact, 2009, 181, 220-226

13 Raval, J.; Desai, K. K; Synthesis and Antimicrobial Activity of New Triazolopyridinyl Phenothiazines. ARKIVOC, 2005, 8, 21. 
Synthesis and antimicrobial activity of [N1(N-substitutedarylidene-hydrazino)-acetyl]2-methyl-imidazoles and [N1-(4-substituted aryl-3-chloro-2-oxo-1-azetidinyl-amino)acetyl]-2-methyl-imidazoles, Proc. Nat. Acad. Sci. India, Sec A, Phys Sci, 2010, 80,117121.

15 Trivedi, P..B.; Undavia, N .K.; Dave, A. M.; Bhatt, K. N.; Desai, N. C.; Synthesis and antimicrobial activity of 4-oxothiazolidines, 4-oxoazetidines, malonanilic acid hydrazines and pyrazoline derivatives of phenothiazine, Indian J Chem, 1993, 32B (7), 760-765.

16 Viveros, M.; Amaral, L.; Design, Synthesis, Characterisation and Antitubarcular Activity of some 2-Heterocycle-Substituted Phenothiazines, Int J Antimicrob Ag, 2001, 17, 225.

17 Amaral, L.; Kristiansen; Phenothiazines: an Alternative to Conventional Therapy for the Initial Management of Suspected Multidrug Resistant Tubercular Activity of some 2Heterocycle-Substituted Phenothiazines, Int J Antimicrob Ag, 2001, 17, 225.

18 Madrid, P. B.; Polgar, W. E.; Toll, L.; Tanga, M. J; Synthesis and antitubercular activity of phenothiazines with reduced binding to dopamine and serotonin receptors, Bioorg Med Chem Let, 2007, 17, 3014-3017.

19 Motohasho, N.; Kawase, M.; Saito, S.; Sakagami, H.; Antitumor Potential and Possible Targets of Phenothiazine-Related Compounds, Curr Drug Targets, 2000, 1, 237-245.

20 Motohasho, N.; Kawase, M.; Saito, S.; kurihara, T.; Satoh, K.; Nakashima, H.; Premanathan, M.; Arakaki, R.; Sakagami, H.; Molnar, J.; Synthesis and Biological Activity of $\mathrm{N}$-acylphenothiazines, Int $\mathrm{J}$ Antimicrob Ag, 2000, 14(3), 203-207.

21 Leancer D. and Mitscher L .A., Organic Chemistry of Drug Synthesis, Vol. I.; John Wiley \& and Sons, New York, 1977, 372-392 and Structure-activity Relationships of Phenothiazine Carboxylic acids having Pyrimidine-dione as Novel Histamine $\mathrm{H}(1)$ Antagonists, Bioorg Med Chem Lett, 2009, 19(10), 2766-2771.

23 Borbely, A. A; Hinkkanen, M. L.; Synthesis and Antifungal Activity of some Substituted Phenothiazines and Related Compounds, Mod Pharmacol Toxicol, 1979, 16, 403-426.

24 Korth, L .H.; Acridine and Phenothiazine Derivatives as Pharmacotherapeutics for Prion Disease, National Academy of Science USA, 2001, 98 (17), 9836-9841.

25 Okafor, C. O.; Okerelu, I. O.; Okeke, S. I.; Vat Dyes from Three New Heterocyclic Ring, Dyes and Pigments, 1986, 8, 11-24.

26 Pathak, V. N.; Yadav, S .S.; Srivastava, R .C.; Indian Sci. Abstr., 1994, 30, 17.

27 Mitchell, S. C.; Mammallian Metabolism of Administered Phenothiazine: Drug Metabolism Rev, 1982, 13: 319-343.

28 Murphy, C .M.; Rarner, H.; Smith, N .L.; Ind. Eng. Chem., 1950, 42, 2479

29 Floyd, R. A.; Scheider, J. E.; Zhu, Y. Q.; North, T. W.; Schinazi, F.; Proc Am Assoc Cancer Res, 1993, 34, 359.

30 Kurihara, T.; Motohashi, N.; Sakagami, H.; Molnar, H.; Relationship between Cytotoxin Activity and Dipole Moment for Phthalimidoand Chloroethyl-phenothiazines, J Anticancer Res, 1999, 19, 4081.

31 Kurihara, T.; Nojima, K.; Sakagami, H.; Molnar, H.; Motohashi, N.; Molnar, H.; Electronic Structure and Cytoxin Activity of "half-mustard type" Phenothiazines by MM3 and PM3 Methods, J Anticancer Res, 1999, 19, 3895.

32 Bauer, A. W; Kibby, W. M. M.; Sherris, J.C.; Turck, M.; Am J Clin Path, 1999, 45, 37.

33 Perez, C.; Pauli, M.; Bazerque, P.; Antibiotic assay by the Agar-well Diffusion Method-Acta Biologiae et Medicine Experimentalis,1990, 15, 113-115.

34 Fries, K.; Ochwat, P.; Beru. Chem. Neues uber, 1923, 56B, 17,3334 